\title{
Persepsi Mahasiswa Akuntansi Reguler dan Non Reguler Universitas Udayana Terhadap Minat Mengikuti Pendidikan Profesi Akuntansi
}

\author{
Ida Ayu Riana Puspita Dewi ${ }^{1}$ \\ Maria Mediatrix Ratna Sari ${ }^{2}$
}

\author{
${ }^{1}$ Fakultas Ekonomi dan Bisnis Universitas Udayana (Unud), Bali, Indonesia \\ email: rianapd1703@gmail.com / Telp: 082237399666 \\ ${ }^{2}$ Fakultas Ekonomi dan Bisnis Universitas Udayana (Unud), Bali, Indonesia
}

\begin{abstract}
ABSTRAK
Pendidikan Profesi Akuntansi merupakan pendidikan lanjutan dalam bidang profesi akuntansi. Penelitian ini bertujuan mengetahui persepsi mahasiswa akuntansi reguler dan non reguler Universitas Udayana terhadap minat mengikuti Pendidikan Profesi Akuntansi yang diukur dari motivasi karir, motivasi kualitas, motivasi sosial, serta biaya pendidikan. Penelitian ini dilakukan pada mahasiswa akuntansi reguler dan non reguler angkatan 2014 di Fakultas Ekonomi dan Bisnis Universitas Udayana. Penentuan sampel menggunakan teknik purposive sampling. Jumlah responden penelitian sebanyak 78 orang dihitung menggunakan rumus Slovin. Metode pengumpulan data dilakukan metode survey dengan teknik kuesioner yang diukur menggunakan skala likert. Teknik analisis data yang digunakan adalah analisis regresi linier berganda. Penelitian ini memperoleh hasil bahwa semakin tinggi motivasi karir, motivasi kualitas, dan motivasi sosial maka semakin besar minat mahasiswa akuntansi reguler dan non reguler Universitas Udayana mengikuti Pendidikan Profesi Akuntansi, sedangkan biaya pendidikan tidak berpengaruh terhadap minat mahasiswa akuntansi reguler dan non reguler Universitas Udayana mengikuti Pendidikan Profesi Akuntansi.
\end{abstract}

Kata kunci: motivasi, minat, pendidikan profesi akuntansi.

ABSTRACT

Accounting Profession Education is an advanced education in the field of accounting profession. This study aims to find out the perception of Udayana University's regular and irregular accounting students to follow Accounting Profession Education as measured by career motivation, quality motivation, social motivation, and education cost. Determination of sample using non probability sampling method with purposive sampling technique. The number of respondents were 78 people who calculated using Slovin formula. Methods of data collection conducted survey method with questionnaire technique measured using Likert scale. Data analysis technique used is multiple linear regression analysis. This study obtained the result that the higher the motivation of career, quality motivation, and social motivation, the greater the interest of regular and irregular accounting students Udayana University followed Professional Accounting Education, while the cost of education does not affect the interests of regular and non regular accounting students Udayana University Accounting Profession.

Keywords: motivation, interest, accounting profession education.

\section{PENDAHULUAN}

Pada era globalisasi saat ini, perkembangan dari berbagai sektor khususnya ekonomi dan pendidikan terus mengalami perubahan dan kemajuan yang sangat 
Ida Ayu Riana Puspita Dewi dan Maria Madiatrix Ratna Sari. Persepsi...

pesat dibandingkan dengan era sebelumnya. Dengan adanya perubahan dan kemajuan yang pesat, peningkatan kualitas hidup menjadi keinginan orang-orang saat ini. Profesi, status sosial, serta penghasilan yang tinggi menjadi motivasi bagi seseorang dalam mewujudkan kehidupan yang lebih baik. Namun dengan adanya persaingan yang ketat, diperlukan seseorang dengan latar belakang pendidikan yang berkualitas dan memiliki kemampuan serta pengalaman kerja agar dapat bersaing dalam dunia kerja. Hal ini yang kemudian turut menjadi pertimbangan bagi para mahasiswa baru dalam memilih jurusan yang nantinya memiliki peluang tinggi untuk mendapatkan kerja di masa yang akan datang.

Sebagian besar mahasiswa jurusan akuntansi mengganggap profesi akuntan sangat dibutuhkan oleh perusahaan dan organisasi khususnya di Indonesia atau secara global di masa yang akan datang (Wheeler, 1983). Asal mula istilah professional menurut Paisey dan Nicholas (2006) yakni apa yang seseorang itu miliki (profess) dimana dalam hal tertentu mereka memiliki pengetahuan yang lebih baik dibandingkan orang lain. Menjadi professional dalam bidang akuntansi salah satunya adalah dengan bekerja menjadi akuntan publik. Jenis pekerjaan yang dapat dilakukan oleh seorang akuntan publik adalah melakukan pemeriksaan laporan keuangan dan jasa konsultasi dalam bidang keuangan.

Keberadaan Akuntan Publik di Indonesia tidak terlepas dari perkembangan jumlah tiap tahunnya. Pertumbuhan jumlah akuntan publik di Indonesia jika ditinjau dari segi kuantitas bisa dikatakan tergolong rendah apabila dibandingkan dengan Negara-Negara lainnya di ASEAN. Perkembangan jumlah akuntan profesional di Negara-Negara ASEAN dapat dilihat dari tabel 1. 
Tabel 1.

Jumlah Akuntan Profesional Negara ASEAN yang Terdaftar dan Jumlah Penduduk tahun 2015

\begin{tabular}{clccc}
\hline No & Negara & $\begin{array}{c}\text { Jumlah Akuntan Profesional } \\
\text { per Januari 2015 }\end{array}$ & $\begin{array}{c}\text { Jumlah Penduduk } \\
\text { dalam ribuan }\end{array}$ & $\begin{array}{c}\text { Persentase } \\
(\%)\end{array}$ \\
\hline 1 & Brunei & 56 & 406,2 & $0,013 \%$ \\
2 & Kamboja & 291 & $14.962,6$ & $0,0019 \%$ \\
3 & Indonesia & 24.587 & $248.818,1$ & $0,0098 \%$ \\
4 & Laos & 176 & $6.644,0$ & $0,0026 \%$ \\
5 & Malaysia & 31.185 & $29.948,0$ & $0,1 \%$ \\
6 & Myanmar & 1.948 & $61.568,0$ & $0,0031 \%$ \\
7 & Filipina & 18.214 & $99.384,5$ & $0,018 \%$ \\
8 & Singapura & 28.891 & $5.399,2$ & $0,53 \%$ \\
9 & Thailand & 62.739 & $68.251,0$ & $0,091 \%$ \\
10 & Vietnam & 9.800 & $89.708,9$ & $0,01 \%$ \\
& Total & 178.517 & $625.090,5$ & $0,77 \%$ \\
\hline
\end{tabular}

Sumber: Data diolah, 2018

Berdasarkan Tabel 1. diatas dapat dilihat bahwa perkembangan jumlah profesi akuntan di Indonesia relatif masih rendah karena jumlah akuntan profesional di Negara Indonesia menduduki peringkat keempat terbanyak setelah Negara Thailand, Malaysia, dan Singapura. Hal ini sangat disayangkan mengingat jumlah penduduk di Indonesia merupakan yang terbesar yaitu mencapai kurang lebih 249 juta penduduk namun hanya memiliki akuntan profesional yang terdaftar sejumlah 24.587 orang. Apabila dibandingkan dengan Negara Thailand, Malaysia, dan Singapura, Negara Indonesia seharusnya memiliki potensi yang lebih besar dalam meningkatkan jumlah akuntan profesional karena didukung oleh banyaknya jumlah penduduk. Hal tersebut menunjukkan bahwa minat masyarakat Indonesia khususnya lulusan akuntansi untuk menjadi seorang akuntan publik masih rendah. Rendahnya perkembangan jumlah akuntan publik di Indonesia dapat disebabkan oleh berbagai faktor yang mempengaruhi minat seorang lulusan akuntansi untuk tidak menjadikan profesi akuntan publik dalam pilihan karirnya. 
Ida Ayu Riana Puspita Dewi dan Maria Madiatrix Ratna Sari. Persepsi...

Pendidikan Profesi Akuntansi (PPAk) merupakan jenjang pendidikan tambahan yang ditujukan bagi seorang lulusan sarjana ekonomi jurusan akuntansi yang ingin mendapatkan gelar Akuntan (Raminten, 2012). Seseorang yang ingin mengikuti Pendidikan Profesi Akuntansi (PPAk) harus berpendidikan paling rendah diploma (D-IV) atau sarjana (S1) lulusan perguruan tinggi.

Tabel 2.

Perkembangan Jumlah Mahasiswa PPAk Fakultas Ekonomi dan Bisnis Universitas Udayana Tahun 2013-2017

\begin{tabular}{|c|c|c|c|c|c|c|c|c|}
\hline \multirow{2}{*}{ Tahun } & \multirow{2}{*}{ Semester } & \multicolumn{3}{|c|}{$\begin{array}{c}\text { Jumlah Mahasiswa } \\
\text { Mendaftar }\end{array}$} & \multicolumn{3}{|c|}{$\begin{array}{c}\text { Jumlah Mahasiswa } \\
\text { Diterima }\end{array}$} & \multirow{2}{*}{$\begin{array}{c}\text { Jumlah } \\
\text { Mahasiswa } \\
\text { Lulus }\end{array}$} \\
\hline & & $\begin{array}{l}\text { Dari } \\
\text { Unud }\end{array}$ & $\begin{array}{l}\text { Luar } \\
\text { Unud }\end{array}$ & Jumlah & $\begin{array}{l}\text { Dari } \\
\text { Unud }\end{array}$ & $\begin{array}{l}\text { Luar } \\
\text { Unud }\end{array}$ & Jumlah & \\
\hline \multirow{2}{*}{2013} & Genap & 23 & 8 & 31 & 20 & 10 & 30 & 29 \\
\hline & Ganjil & 20 & 11 & 31 & 18 & 6 & 24 & 28 \\
\hline \multirow{2}{*}{2014} & Genap & 15 & 11 & 26 & 14 & 8 & 22 & 23 \\
\hline & Ganjil & 14 & 2 & 16 & 11 & 10 & 21 & 13 \\
\hline \multirow{2}{*}{2015} & Genap & 10 & 17 & 27 & 10 & 10 & 20 & 23 \\
\hline & Ganjil & 13 & 13 & 26 & 11 & 2 & 13 & 23 \\
\hline \multirow{2}{*}{2016} & Genap & 5 & 23 & 28 & 5 & 16 & 21 & 22 \\
\hline & Ganjil & 3 & 8 & 11 & 3 & 13 & 16 & 9 \\
\hline \multirow{2}{*}{2017} & Genap & 7 & 8 & 15 & 7 & 19 & 26 & 17 \\
\hline & Ganjil & 10 & 9 & 19 & 9 & 6 & 15 & 14 \\
\hline
\end{tabular}

Berdasarkan Tabel 2. menunjukkan bahwa jumlah mahasiswa dari Universitas Udayana yang mendaftar pada program PPAk dari semester genap tahun 2013 hingga semester genap tahun 2015 jumlah mahasiswa yang mendaftar mengalami penurunan. Jumlah mahasiswa yang mendaftar pada program PPAk dari tahun 2013 hingga tahun 2017 mengalami fluktuasi dengan kecenderungan mengalami penurunan. Hal tersebut menunjukkan bahwa minat mahasiswa akuntansi khususnya dari Universitas Udayana terhadap peningkatan kualitas profesi akuntan relatif masih rendah. 
Rendahnya minat untuk mengikuti PPAk juga disebabkan dengan dikeluarkannya Peraturan Menteri Keuangan Nomor 216/PMK.01/2017 tentang Akuntan beregister Negara. Dimana dengan dikeluarkannya peraturan tersebut, lulusan PPAk tidak langsung mendapat ijazah serta mendapat gelar Akuntan beregister Negara. Untuk dapat memperoleh gelar Akuntan beregister Negara, seseorang harus mengikuti ujian sertifikasi profesi akuntansi terlebih dahulu dan memiliki bukti lulus ujian sertifikasi profesi akuntansi yang diselenggarakan oleh Asosiasi Profesi Bidang Akuntansi, menjadi anggota Asosiasi Profesi Bidang Akuntansi, berpengalaman praktik di bidang akuntansi paling sedikit tiga tahun, dan memiliki Nomor Pokok Wajib Pajak. PMK ini dibentuk bertujuan untuk mewujudkan terciptanya akuntan yang profesional dan mempunyai daya saing di tingkat global.

Masyarakat mengenal suatu profesi bergantung dari usaha yang dilakukan dan jasa apa yang diberikan professional pada masyarakat sesuai dengan keahlian yang dimiliki (Chua et al., 1991). Pada umumnya profesi akuntan diperlukan pada empat bidang, yakni public accounting, private accounting, non-for-profit accounting, dan pendidik (Weygant et.al., 1996). Di tengah tuntutan untuk menjadi profesional terutama untuk menjadi seorang akuntan, persepsi masingmasing mahasiswa akuntansi terhadap PPAk menjadi faktor penting karena persepsi dari masing- masing mahasiswa yang nantinya akan memengaruhi minat mahasiswa itu untuk mengikuti PPAk. Minat memiliki pengaruh yang cukup kuat dalam pencapaian prestasi pada suatu pekerjaan, jabatan atau karir. Suatu 
Ida Ayu Riana Puspita Dewi dan Maria Madiatrix Ratna Sari. Persepsi...

pekerjaan tentunya tidak dapat terselesaikan dengan baik apabila seseorang tidak memiliki minat untuk menyelesaikan pekerjaan tersebut.

Penelitian ini dilakukan untuk meneliti kembali apakah penelitian sebelumnya konsisten dengan penelitian yang berlaku saat ini. Penelitian ini merupakan replikasi dari penelitian yang dilakukan oleh Aryani (2015). Perbedaan penelitian sebelumnya dengan penelitian ini terdapat pada responden dan variabel penelitian. Pada penelitian yang dilakukan oleh Aryani (2015) responden penelitian yang dipilih adalah mahasiswa PPAk dan variabel yang dipilih meliputi motivasi kualitas, motivasi karir, motivasi ekonomi, biaya pendidikan, dan minat mengikuti PPAk. Sedangkan dalam penelitian ini responden yang dipilih adalah mahasiswa akuntansi reguler dan non reguler angkatan 2014. Variabel yang dipilih dalam penelitian ini meliputi, motivasi karir, motivasi kualitas, motivasi sosial, biaya pendidikan, dan minat mengikuti PPAk.

Penelitian ini bertujuan untuk menganalisis pengaruh motivasi karir, motivasi kualitas, motivasi sosial dan biaya pendidikan terhadap minat mahasiswa akuntansi reguler dan non reguler Fakultas Ekonomi dan Bisnis Universitas Udayana mengikuti pendidikan profesi akuntansi (PPAk). Penelitian ini diharapkan dapat digunakan sebagai tambahan pengetahuan mengenai pengaruh persepsi mahasiswa akuntansi terhadap minat mengikuti Pendidikan Profesi Akuntansi (PPAk), serta dapat memberikan bukti empiris atas teori kebutuhan sehingga dapat meningkatkan mutu pembelajaran pendidikan akuntansi. Hasil penelitian ini juga diharapkan dapat menjadi referensi serta memberikan sumbangan konseptual bagi penelitian selanjutnya. 
Karir dipandang sebagai rangkaian promosi untuk memperoleh pekerjaan yang mempunyai beban pertanggungjawaban lebih tinggi atau penempatan posisi yang lebih baik dengan tujuan agar mereka memiliki kehidupan karir yang memuaskan (Kermis, 2011). Motivasi Karir sebagai multidimensi yang terdiri dari tiga unsur utama, yaitu ketahanan karir, wawasan karir dan identitas karir (Alniacik et. al, 2012). Teori yang mendukung motivasi karir yaitu teori kebutuhan yang dikemukakan oleh MCClelland menunjukkan bahwa setiap individu termotivasi oleh berbagai kebutuhan salah satunya yaitu kebutuhan akan kekuasaan (need of power) yang sangat berhubungan dengan kebutuhan untuk mencapai suatu posisi kepemimpinan (Robbins dan Judge, 2015).

Karir merupakan perkembangan atau kemajuan yang dialami seseorang terkait dengan kehidupan, jabatan, maupun pekerjaannya yang dimana dapat ditunjukkan melalui kemampuan yang dimiliki. Institusi pendidikan seperti halnya perguruan tinggi berperan besar dalam pemilihan dan perkembangan karir seseorang. Zyl dan Villiers (2011) menyatakan mahasiswa akuntansi yang berminat untuk melanjutkan karirnya menjadi akuntan publik mengharapkan adanya kepuasan kerja sesuai dengan heahlian yang dimiliki di bidang akuntansi serta dapat memperoleh penghasilan yang potensial. Motivasi untuk memiliki karir yang berkembang di masa depan menjadi pertimbangan bagi para mahasiswa untuk melanjutkan pendidikan ke PPAk.

Perkembangan terhadap karir diakibatkan karena adanya peningkatan terhadap skill setelah mengikuti pendidikan profesi. Bagi seorang pegawai, karir bahkan dianggap lebih penting dari pada pekerjaan itu sendiri (Walker, 1998). 
Ida Ayu Riana Puspita Dewi dan Maria Madiatrix Ratna Sari. Persepsi...

Hasil penelitian yang dilakukan oleh Fikri (2010), Kusumastuti dan Waluyo (2013), Aryani (2015) dan Setyaningsih (2016) menunjukkan bahwa motivasi karir berpengaruh positif terhadap minat mahasiswa akuntansi untuk mengikuti PPAk. Berdasarkan penjelasan di atas, hipotesis yang dapat dirumuskan dalam penelitian adalah sebagai berikut:

$\mathrm{H}_{1}$ : Motivasi karir berpengaruh positif terhadap minat mahasiswa akuntansi reguler dan non reguler Universitas Udayana mengikuti PPAk.

Kualitas didefinisikan sebagai suatu tingkatan atau ukuran yang menunjukkan karakteristik tertentu (Besterfield, 2003). Kualitas merupakan kondisi dinamis yang berhubungan dengan produk, jasa, sumber daya manusia, proses, dan lingkungan yang memenuhi atau melebihi harapan (Goetsch dan Stanley, 2002). Kualitas merupakan totalitas bentuk dan karakteristik barang atau jasa yang menunjukkan kemampuannya untuk memuaskan kebutuhan yang tampak jelas maupun tersembunyi (Render dan Herizer, 2004). (Bobby dalam Schindler et al., 2015) menyatakan kualitas merupakan istilah yang memiliki bermacam-macam interpretasi tergantung pandangan dari pemangku kepentingan. Elemen kualitas dan kompensasi menjadi hal yang diperhatikan dalam profesi akuntansi, khususnya profesi akuntan publik, terlebih elemen ini dimasukkan ke dalam standar audit (Rahardian, 2008). Teori yang mendukung motivasi kualitas yaitu teori kebutuhan yang dikemukakan oleh MCClelland menunjukkan bahwa setiap individu termotivasi oleh berbagai kebutuhan salah satunya yaitu kebutuhan akan pencapaian (need of achievement), yaitu dorongan untuk berprestasi, untuk 
pencapaian yang berhubungan dengan serangkaian standar, dan berusaha untuk berhasil (Robbins dan Judge, 2015).

Taraf peningkatan kualitas serta kemampuan dapat diukur melalui seberapa kuat minat yang dimiliki oleh seseorang. Motivasi untuk meningkatkan kemampuan diri terutama dalam bidang akuntansi menjadi pertimbangan bagi para mahasiswa akuntansi untuk melanjutkan pendidikan ke PPAk. PPAk dapat berkontribusi dalam peningkatan kualitas diri seseorang sehingga dapat menjadi akuntan yang profesional. Hasil penelitian yang dilakukan oleh, Kusumastuti dan Waluyo (2013), Widyastuti dan Juliana (2004), Aryani (2015) dan Condrorini (2015) menyatakan bahwa motivasi kualitas berpengaruh positif terhadap minat mahasiswa akuntansi untuk mengikuti PPAk. Berdasarkan penjelasan di atas, hipotesis yang dapat dirumuskan dalam penelitian ini adalah:

$\mathrm{H}_{2}$ : Motivasi kualitas berpengaruh positif terhadap minat mahasiswa akuntansi reguler dan non reguler Universitas Udayana mengikuti PPAk.

Akerlof (2006) menyatakan bahwa motivasi sosial dapat menyebabkan individu untuk berperilaku berbeda karena terkait dengan adanya motivasi ekonomi yang melatarbelakanginya. Buss (1997) mengemukakan pentingnya status sebagai motivasi sosial akan sangat berpengaruh terhadap tingkat kecemasan yang dialami seseorang, disamping itu motivasi sosial secara psikologis mampu mengabaikan peran dari jenis kelamin seseorang. Teori yang mendukung motivasi sosial yaitu Teori Hierarki Kebutuhan yang dikemukakan oleh Abraham Maslow menunjukkan kebutuhan hidup manusia mulai dari yang mendasar hingga kebutuhan yang lebih tinggi. 
Ida Ayu Riana Puspita Dewi dan Maria Madiatrix Ratna Sari. Persepsi...

Motivasi sosial dapat menjadi pertimbangan bagi mahasiswa untuk melanjutkan pendidikannya mengikuti PPAk. Dengan mendapat sebutan akuntan, maka muncul kepuasan dalam diri seseorang karena kemampuan yang dimiliki atau prestasi yang diraih mendapat apresisasi oleh orang lain dan lingkungan sekitarnya. Hasil penelitian oleh Indrawati (2009), dan Nurhayani (2012) menemukan adanya pengaruh positif motivasi sosial terhadap minat mahasiswa akuntansi mengikuti PPAk. Hipotesis yang dapat dirumuskan dalam penelitian adalah sebagai berikut:

$\mathrm{H}_{3}$ : Motivasi sosial berpengaruh positif terhadap minat mahasiswa akuntansi reguler dan non reguler Universitas Udayana mengikuti PPAk.

Pengorbanan finansial berupa biaya pendidikan dikeluarkan untuk mendapatkan manfaat di masa depan. Penelitian yang dilakukan oleh Rahayu dan Rusmawan (2010) menyatakan bahwa biaya kuliah adalah salah satu faktor yang berpengaruh pada minat seseorang mengikuti PPAk. Sehingga dapat dikatakan bahwa proses pendidikan tidak akan dapat berjalan apabila tidak didukung oleh biaya pendidikan.

Biaya pendidikan dapat menjadi pertimbangan bagi mahasiswa dalam melanjutkan pendidikannya mengikuti PPAk. Hal ini didukung oleh penelitian yang dilakukan oleh Setyaningsih (2016) dan Mahadwija (2017) yang menunjukkan adanya pengaruh positif biaya pendidikan terhadap minat mahasiswa akuntansi mengikuti PPAk. Berdasarkan uraian di atas, maka hipotesis yang akan dirumuskan dalam penelitian adalah sebagai berikut:

$\mathrm{H}_{4}$ : Biaya pendidikan berpengaruh positif terhadap minat mahasiswa akuntansi reguler dan non reguler Universitas Udayana mengikuti PPAk. 
ISSN: 2302-8556

E-Jurnal Akuntansi Universitas Udayana

Vol.25.3.Desember (2018): 2242- 2268

\section{METODE PENELITIAN}

Desain penelitian ini menggunakan pendekatan kuantitatif yang berbentuk asosiatif. Metode penelitian kuantitatif dapat diartikan sebagai metode penelitian yang berlandaskan positivisme, dan metode ini telah memenuhi kaidah-kaidah ilmiah yaitu konkrit/empiris, obyektif, terukur, rasional, dan sistematis. Penelitian berbentuk asosiatif merupakan penelitian yang bertujuan mengetahui hubungan antara dua variabel atau lebih. Desain penelitian ini dijelaskan dalam Gambar 1.

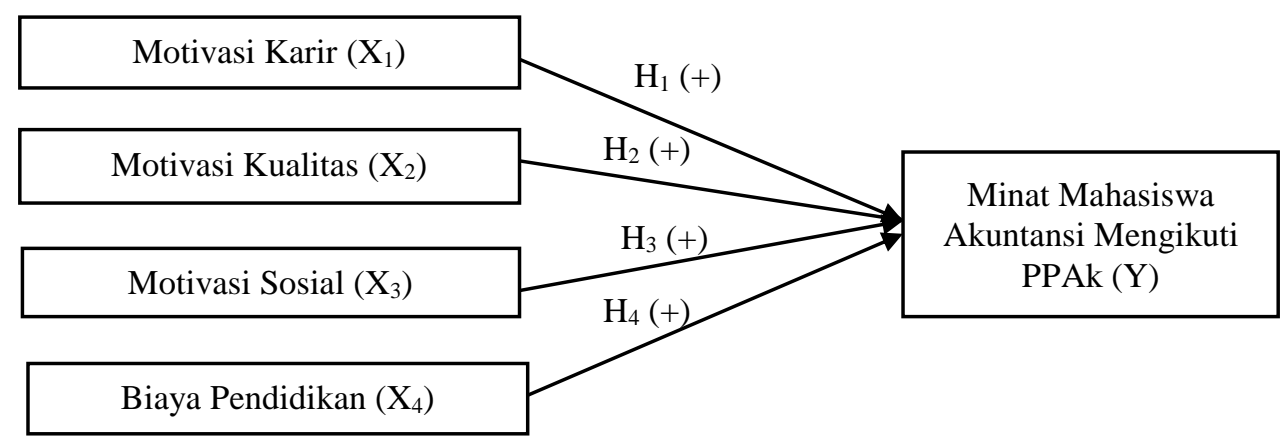

\section{Gambar 1. \\ Desain Penelitian}

Lokasi penelitian ini dilakukan di Fakultas Ekonomi dan Bisnis Universitas Udayana. Alasan dipilihnya lokasi penelitian karena penelitian ini akan meneliti mengenai persepsi antara mahasiswa akuntansi program reguler dan non reguler angkatan 2014 dan karena sebagian besar mahasiswa yang mengikuti PPAk Universitas Udayana berasal dari Fakultas Ekonomi dan Bisnis Universitas Udayana. Variabel bebas yang digunakan dalam penelitian ini adalah motivasi karir, motivasi kualitas, motivasi sosial, dan biaya pendidikan. Variabel terikat dalam penelitian ini adalah minat mahasiswa akuntansi mengikuti PPAk. 
Ida Ayu Riana Puspita Dewi dan Maria Madiatrix Ratna Sari. Persepsi...

Penelitian ini menggunakan jenis data kualitatif dan data kuantitatif. Data kualitatif yang digunakan dalam penelitian ini adalah nama-nama mahasiswa akuntansi reguler dan non reguler program S1 angkatan 2014, indikator dalam kuesioner, serta gambaran umum program PPAk Fakultas Ekonomi dan Bisnis Universitas Udayana. Data kuantitatif yang digunakan adalah skor atau jawaban dari pernyataan-pernyataan yang terdapat dalam kuesioner.

Penelitian ini menggunakan sumber data primer dan data sekunder. Dalam penelitian ini data primer diperoleh dari jawaban kuesioner yang telah disebar kepada seluruh mahasiswa akuntansi reguler dan non reguler angkatan 2014 di Fakultas Ekonomi dan Bisnis Universitas Udayana. Dalam penelitian ini yang merupakan data sekunder adalah data yang diperoleh dari program PPAk Universitas Udayana.

Populasi yang digunakan dalam penelitian ini seluruh mahasiswa aktif jurusan akuntansi program S1 reguler maupun non reguler angkatan 2014 di Fakultas Ekonomi dan Bisnis Universitas Udayana. Alasan pemilihan mahasiswa angkatan 2014 adalah mahasiswa pada tingkat ini telah memasuki semester 7 yang merupakan tahun terakhir dalam perkuliahannya dan tentunya telah memiliki rencana ke depan setelah menyelesaikan program sarjana (S1). Populasi mahasiswa akuntansi angkatan 2014 dijelaskan dalam tabel 3. 
ISSN: 2302-8556

Tabel 3.

Jumlah Mahasiswa Aktif Akuntansi Reguler dan Non Reguler Angkatan 2014 Fakultas Ekonomi dan Bisnis Universitas Udayana

\begin{tabular}{|c|c|}
\hline Program & Jumlah Mahasiswa Aktif \\
\hline Reguler & 179 \\
\hline Non Reguler & 186 \\
\hline Total & 365 \\
\hline
\end{tabular}

Pengambilan sampel dalam penelitian ini menggunakan metode nonprobability sampling dengan teknik purposive sampling. Adapun kriteria sampel yang ditentukan dalam penelitian ini adalah: 1) Mahasiswa akuntansi reguler dan non reguler program S1 angkatan 2014 di Fakultas Ekonomi dan Bisnis Universitas Udayana yang telah mengikuti mata kuliah Pengauditan serta Praktikum Pengauditan. Alasan dipilih mahasiswa yang telah mengikuti mata kuliah Pengauditan dan Praktikum Pengauditan karena diharapkan mahasiswa yang mengikuti mata kuliah tersebut telah memiliki gambaran atau pengetahuan mengenai profesi seorang akuntan publik; 2) Mahasiswa akuntansi yang bisa ditemui dan bersedia menjadi responden; 3) Mahasiswa yang berstatus aktif dan tidak melakukan cuti perkuliahan. Berdasarkan perhitungan sampel dengan menggunakan rumus Slovin, maka jumlah sampel yang diperoleh sebanyak 78,495 yang akan dibulatkan menjadi 78 responden.

Metode pengumpulan data dalam penelitian ini menggunakan metode survey dengan teknik kuesioner. Skala pengukuran yang digunakan dalam penelitian ini menggunakan metode skala Likert, dimana skor $1=$ sangat tidak setuju (STS), skor 2 = tidak setuju (TS), skor $3=$ setuju (S), dan skor $4=$ sangat setuju (SS). Teknik analisis data dalam penelitian ini menggunakan analisis 
Ida Ayu Riana Puspita Dewi dan Maria Madiatrix Ratna Sari. Persepsi...

regresi linier berganda yang merupakan pengujian yang dilakukan untuk mengetahui ada atau tidaknya pengaruh antara dua variabel yaitu variabel bebas dengan variabel terikat. Pengujian ini dilakukan dengan menggunakan bantuan program Statistical Product and Service Solution. Pengujian analisis regresi linier berganda dirumuskan sebagai berikut:

$Y=\alpha+\beta_{1} X_{1}+\beta_{2} X_{2}+\beta_{3} X_{3}+\beta_{4} X_{4}+e$

Keterangan:

Y : Minat Mengikuti Pendidikan Profesi Akuntansi

$\alpha \quad$ : Konstanta

$\beta_{1}-\beta_{4} \quad$ : Koefisien Regresi

$\mathrm{X}_{1} \quad$ : Motivasi Karir

$\mathrm{X}_{2} \quad$ : Motivasi Kualitas

$\mathrm{X}_{3} \quad$ : Motivasi Sosial

$\mathrm{X}_{4} \quad$ : Biaya Pendidikan

e : Standar error

\section{HASIL DAN PEMBAHASAN}

Uji validitas dilakukan dengan menghitung korelasi antara skor masing-masing butir pertanyaan dengan total skor sehingga diperoleh nilai Pearson Correlation. Hasil uji validitas dalam penelitian ini menunjukkan bahwa semua instrumen penelitian yang digunakan untuk mengukur variabel penelitian, memiliki Pearson Correlation di atas 0,30 sehingga seluruh indikator yang digunakan dinyatakan valid.

Uji reliabilitas dilakukan untuk menunjukkan sejauh mana suatu pengukuran kembali terhadap gejala yang sama. Suatu instrument dikatakan reliabel apabila instrument tersebut telah beberapa kali digunakan untuk mengukur objek yang sama dan menghasilkan data atau jawaban yang sama dari waktu ke waktu. 
Hasil uji reliabilitas dalam penelitian ini menunjukkan bahwa setiap variabel memiliki nilai koefisien Alpha Cronbach lebih besar dari 0,70 (>0,70). Semua variabel dalam penelitian ini adalah reliabel dan pernyataan dalam kuesioner layak digunakan sebagai alat ukur.

Hasil uji normalitas pada penelitian ini diperoleh nilai signifikansi sebesar 0,762 dimana nilai signifikansi tersebut lebih besar dari 0,05 , maka dapat disimpulkan bahwa data terdistribusi secara normal. Uji Multikolinearitas bertujuan untuk menguji apakah terdapat korelasi antar masing-masing variabel bebas (variabel independen). Model regresi dikatakan baik apabila tidak terjadi korelasi diantara variabel bebas. Multikolineritas dapat dideteksi dari tolerance dan nilai Variance Inflation Factor (VIF). Hasil uji multikolinearitas pada penelitian ini menunjukkan bahwa nilai tolerance pada masing-masing variabel lebih besar dari $0,10(>0,10)$ dan nilai VIF pada masing-masing variabel kurang dari $10(<10)$. Dapat disimpulkan bahwa data penelitian terbebas dari multikolinearitas.

Hasil uji heterokedastisitas pada penelitian ini menunjukkan tingkat signifikansi dari masing-masing variabel bebas di atas 0,05 , sehingga dapat disimpulkan bahwa model regresi terbebas dari heterokedastisitas. Berdasarkan hasil uji normalitas, uji multikolinearitas dan uji heteroskedastisitas yang diperoleh maka dapat dinyatakan model regresi penelitian ini lolos uji asumsi klasik 
Tabel 4.

Hasil Statistik Deskriptif

\begin{tabular}{lccccc}
\hline \multicolumn{1}{c}{ Variabel } & N & Minimum & Maximum & Mean & Deviasi Standar \\
\hline Motivasi Karir & 78 & 29 & 40 & 37,33 & 2,771 \\
Motivasi Kualitas & 78 & 25 & 36 & 29,41 & 2,817 \\
Motivasi Sosial & 78 & 12 & 20 & 16,18 & 1,836 \\
Biaya Pendidikan & 78 & 10 & 19 & 13,82 & 1,544 \\
Minat Mengikuti PPAk & 78 & 11 & 20 & 16,45 & 1,842 \\
\hline
\end{tabular}

Sumber: Data diolah, 2018

Berdasarkan Tabel 4. menunjukkan hasil statistik deskriptif yaitu variabel motivasi karir $\left(\mathrm{X}_{1}\right)$ memiliki nilai minimum sebesar 29 , nilai maksimum sebesar 40, nilai rata-rata sebesar 37,33 . Nilai rata-rata sebesar 37,33 dimana nilai tersebut mendekati nilai maksimal artinya motivasi karir yang dimiliki oleh mahasiswa akuntansi reguler dan non reguler Universitas Udayana cenderung tinggi. Deviasi standar pada variabel motivasi karir sebesar 2,771. Hal tersebut menunjukkan bahwa standar penyimpangan data terhadap nilai rata-ratanya adalah 2,771 , data penelitian menunjukkan responden penelitian memiliki motivasi karir yang tinggi.

Variabel motivasi kualitas $\left(\mathrm{X}_{2}\right)$ memiliki nilai minimum sebesar 25, nilai maksimum sebesar 36, nilai rata-rata sebesar 29,41. Nilai rata-rata sebesar 29,41 dimana nilai tersebut mendekati nilai minimal artinya motivasi kualitas yang dimiliki oleh mahasiswa akuntansi reguler dan non reguler Universitas Udayana cenderung rendah. Deviasi standar pada variabel motivasi kualitas sebesar 2,817. Data penelitian menunjukkan responden penelitian memiliki sebaran data yang merata.

Variabel motivasi sosial $\left(\mathrm{X}_{3}\right)$ memiliki nilai minimum sebesar 12 , nilai maksimum sebesar 20 , nilai rata-rata sebesar 16,18 . Nilai rata-rata sebesar 16,18 dimana nilai tersebut mendekati nilai maksimal artinya motivasi sosial yang 
dimiliki oleh mahasiswa akuntansi reguler dan non reguler Universitas Udayana cenderung tinggi. Deviasi standar pada variabel motivasi sosial sebesar 1,836. Data penelitian menunjukkan responden penelitian memiliki sebaran data yang merata.

Variabel biaya pendidikan $\left(\mathrm{X}_{4}\right)$ memiliki nilai minimum sebesar 10 , nilai maksimum sebesar 19 , nilai rata-rata sebesar 13,82 . Nilai rata-rata sebesar 13,82 dimana nilai tersebut mendekati nilai minimal artinya biaya pendidikan yang dimiliki oleh mahasiswa akuntansi reguler dan non reguler Universitas Udayana cenderung rendah. Deviasi standar pada variabel biaya pendidikan sebesar 1,544. Data penelitian menunjukkan responden penelitian memiliki sebaran data yang merata.

Variabel minat mengikuti PPAk (Y) memiliki nilai minimum sebesar 11, nilai maksimum sebesar 20 , nilai rata-rata sebesar 16,45 . Nilai rata-rata sebesar 16,45 dimana nilai tersebut mendekati nilai maksimal artinya minat mengikuti PPAk yang dimiliki oleh mahasiswa akuntansi reguler dan non reguler Universitas Udayana cenderung tinggi. Deviasi standar pada variabel minat mengikuti PPAk sebesar 1,842, data penelitian menunjukkan responden penelitian memiliki sebaran data yang merata. 
Tabel 5.

Hasil Analisis Regresi Linier Berganda

\begin{tabular}{lccccc}
\hline \multirow{2}{*}{ Variabel } & \multicolumn{2}{c}{$\begin{array}{c}\text { Unstandardized } \\
\text { Coeficient }\end{array}$} & $\begin{array}{c}\text { Standardized } \\
\text { Coeficient }\end{array}$ & T & Signifikansi \\
\cline { 2 - 4 } & $\mathbf{B}$ & Std. Eror & Beta & & \\
\hline Constant & $-0,154$ & 3,301 & & $-0,047$ & 0,963 \\
Motivasi Karir $\left(\mathrm{X}_{1}\right)$ & 0,128 & 0,064 & 0,193 & 2,009 & 0,048 \\
Motivasi Kualitas $\left(\mathrm{X}_{2}\right)$ & 0,174 & 0,080 & 0,267 & 2,180 & 0,032 \\
Motivasi Sosial $\left(\mathrm{X}_{3}\right)$ & 0,298 & 0,076 & 0,297 & 2,473 & 0,016 \\
Biaya Pendidikan $\left(\mathrm{X}_{4}\right)$ & 0,136 & 0,092 & 0,114 & 1,143 & 0,257 \\
Adjusted R Square & & & 0,299 & & \\
F hitung & & & 9,197 & & \\
Signifikansi F & & & 0,000 & & \\
\hline Sumber: Data diolah, 2018 & & & & &
\end{tabular}

Hasil analisis regresi linier berganda dapat dilihat pada Tabel 5 .

Berdasarkan Tabel 5. diketahui konstanta besarnya -0,154 dengan $p$ value sebesar 0,963 mengandung arti jika motivasi karir $\left(\mathrm{X}_{1}\right)$, motivasi kualitas $\left(\mathrm{X}_{2}\right)$, motivasi sosial $\left(\mathrm{X}_{3}\right)$, dan biaya pendidikan $\left(\mathrm{X}_{4}\right)$ memiliki konstanta tidak sama dengan 0 dianggap tidak mempunyai makna, maka nilai pada minat mengikuti PPAk (Y) adalah sebesar $-0,154$. Nilai koefisien $\beta_{1}$ sebesar 0,128 mempunyai arti bahwa jika variabel motivasi karir $\left(\mathrm{X}_{1}\right)$ meningkat, maka akan menyebabkan peningkatan pada minat mengikuti PPAk (Y), dengan asumsi variabel bebas lainnya dianggap konstan. Nilai koefisien $\beta_{2}$ sebesar 0,174 mempunyai arti bahwa jika variabel motivasi kualitas $\left(\mathrm{X}_{2}\right)$ meningkat, maka akan menyebabkan peningkatan pada minat mengikuti PPAk (Y), dengan asumsi variabel bebas lainnya dianggap konstan. Nilai koefisien $\beta_{3}$ sebesar 0,298 mempunyai arti bahwa jika variabel motivasi sosial $\left(\mathrm{X}_{3}\right)$ meningkat, maka akan menyebabkan peningkatan pada minat mengikuti PPAk (Y), dengan asumsi variabel bebas lainnya dianggap konstan. Nilai koefisien $\beta_{4}$ sebesar 0,136 mempunyai arti bahwa jika variabel biaya 
pendidikan $\left(\mathrm{X}_{4}\right)$ meningkat, maka akan menyebabkan peningkatan pada minat mengikuti PPAk (Y), dengan

Hasil analisis koefisien determinasi dalam penelitian ini dilihat dari nilai Adjusted $R$ Square sebesar 0,299. Hasil tersebut memiliki arti bahwa pengaruh variabel motivasi karir, motivasi kualitas, motivasi sosial, serta biaya pendidikan pada minat mengikuti PPAk adalah sebesar 29,9\%, sedangkan sisanya yaitu sebesar 70,1\% dipengaruhi oleh variabel lain di luar model penelitian. Hasil uji $\mathrm{F}$ menunjukkan bahwa nilai $\mathrm{F}$ hitung sebesar 9,197 dengan nilai signifikansi 0,000. Sehingga model penelitian dikatakan layak digunakan sebagai model regresi.

Nilai koefisien regresi motivasi karir $\left(\mathrm{X}_{1}\right)$ sebesar 2,009 dengan nilai $p$ value sebesar 0,048. Nilai $p$ value sebesar $0,048<0,05$ maka $\mathrm{H}_{0}$ ditolak dan $\mathrm{H}_{1}$ diterima. Penelitian ini didukung oleh Teori Kebutuhan yang dikemukakan oleh MCClelland yang menunjukkan bahwa setiap individu termotivasi oleh berbagai kebutuhan salah satunya yaitu kebutuhan akan kekuasaan yang sangat berhubungan dengan kebutuhan untuk mencapai suatu posisi kepemimpinan (Robbins dan Judge, 2015).

Keinginan untuk memiliki karir yang lebih baik dapat memotivasi seseorang untuk meningkatkan keahlian serta kualitas dalam dirinya sehingga dapat mendorong minat seseorang untuk menempuh pendidikan lebih tinggi yang menunjang karirnya (Cheng et al., 2001). Sebagian besar mahasiswa akuntansi beranggapan bahwa PPAk sebagai sarana pendidikan yang memiliki kontribusi positif untuk meningkatkan keahlian dan mendapatkan karir yang lebih baik di masa yang akan datang. Hasil penelitian ini konsisten dengan penelitian yang 
Ida Ayu Riana Puspita Dewi dan Maria Madiatrix Ratna Sari. Persepsi...

dilakukan oleh Fikri (2010), Kusumastuti dan Waluyo (2013), Aryani (2015) dan Setyaningsih (2016).

Hasil pengujian hipotesis kedua menunjukkan bahwa variabel motivasi kualitas berpengaruh positif terhadap minat mahasiswa akuntansi reguler dan non reguler mengikuti PPAk. Berdasarkan hasil perhitungan pada Tabel 5 diketahui bahwa nilai koefisien regresi motivasi kualitas $\left(\mathrm{X}_{2}\right)$ sebesar 2,180 dengan $p$ value sebesar 0,032. Nilai $p$ value sebesar $0,032<0,05$ maka $\mathrm{H}_{0}$ ditolak dan $\mathrm{H}_{1}$ diterima. Penelitian ini didukung oleh Teori Kebutuhan yang dikemukakan oleh MCClelland menunjukkan bahwa setiap individu termotivasi oleh berbagai kebutuhan salah satunya yaitu kebutuhan akan pencapaian (need of achievement), yaitu dorongan untuk berprestasi, untuk pencapaian yang berhubungan dengan serangkaian standar, dan berusaha untuk berhasil (Robbins dan Judge, 2015).

Kualitas pendidikan seseorang tentunya sangat dipengaruhi oleh tingkat pendidikan yang telah ditempuh. Selama ini PPAk dipandang sebagai salah satu sarana pendidikan yang dapat meningkatkan kualitas terutamanya dalam bidang akuntansi. Hasil penelitian ini konsisten dengan penelitian yang dilakukan oleh Kusumastuti dan Waluyo (2013), Aryani (2015), dan Condrorini (2015). Hal ini memiliki arti bahwa semakin tinggi motivasi kualitas yang dimiliki seseorang, maka akan semakin meningkatkan minat mahasiswa akuntansi dalam mengikuti PPAk.

Hasil pengujian hipotesis ketiga menunjukkan bahwa variabel motivasi sosial berpengaruh positif terhadap minat mahasiswa akuntansi reguler dan non reguler mengikuti PPAk. Berdasarkan hasil perhitungan pada Tabel 5 diketahui bahwa 
nilai koefisien regresi motivasi sosial $\left(\mathrm{X}_{3}\right)$ sebesar 2,473 dengan $p$ value sebesar 0,016. Nilai $p$ value sebesar $0,016<0,05$ maka $\mathrm{H}_{0}$ ditolak dan $\mathrm{H}_{1}$ diterima. Penelitian ini didukung oleh Teori Hierarki Kebutuhan yang dikemukakan Abraham Maslow yaitu kebutuhan sosial (social needs), kebutuhan akan rasa cinta dan kepuasan dalam menjalin hubungan dengan orang lain, kebutuhan akan kepuasan dan perasaan memiliki serta diterima dalam suatu kelompok serta kebutuhan akan penghargaan (esteem needs), yaitu kebutuhan akan status dan kedudukan, kehormatan diri, reputasi, dan prestasi (Lubis, 2014).

Adanya motivasi sosial terhadap minat mengikuti PPAk berkaitan dengan kebutuhan seseorang untuk mendapatkan kepuasan diri dalam hal bekerjasama dan berhubungan dengan orang lain serta mendapat penghargaan maupun pengakuan dari lingkungan sekitar terhadap pencapaian yang telah dilakukan. Hasil penelitian ini konsisten dengan penelitian yang dilakukan oleh Indrawati (2009) dan Nurhayani (2012) yang menyatakan bahwa motivasi sosial berpengaruh positif terhadap minat mahasiswa akuntansi mengkuti PPAk.

Hasil pengujian hipotesis keempat menunjukkan bahwa variabel biaya pendidikan tidak berpengaruh terhadap minat mahasiswa akuntansi reguler dan non reguler Universitas Udayana untuk mengikuti PPAk. Berdasarkan hasil perhitungan pada Tabel 5 diketahui bahwa nilai koefisien regresi biaya pendidikan $\left(\mathrm{X}_{4}\right)$ sebesar 1,143 dengan $p$ value sebesar 0,257 . Nilai $p$ value sebesar $0,257>$ 0,05 maka $\mathrm{H}_{0}$ diterima sedangkan $\mathrm{H}_{1}$ ditolak. Biaya kuliah adalah faktor pendorong minat seseorang mengikuti PPAk (Rahayu dan Rusmawan, 2010). Pernyataan tersebut tidak didukung dalam penelitian ini karena hasil dari 
Ida Ayu Riana Puspita Dewi dan Maria Madiatrix Ratna Sari. Persepsi...

penelitian ini menunjukkan bahwa variabel biaya pendidikan tidak berpengaruh terhadap minat mahasiswa untuk mengikuti PPAk. Dapat dikatakan bahwa tanpa adanya dukungan dari biaya pendidikan maka proses pendidikan akan sulit untuk dilanjutkan. Namun, biaya pendidikan yang cenderung mahal tentunya dapat menjadi salah satu penghambat minat mahasiswa untuk melanjutkan pendidikannya ke PPAk.

Walaupun mahasiswa tersebut memiliki motivasi yang kuat untuk mengikuti PPAk, namun apabila mahasiswa tersebut tidak memiliki biaya untuk melanjutkan pendidikan tentunya mahasiswa tersebut tidak akan dapat mengikuti PPAk. Lain halnya apabila diberikan potongan biaya atau beasiswa untuk mengikuti PPAk, maka akan semakin banyak menarik minat mahasiswa untuk melanjutkan pendidikannya ke PPAk. Hasil penelitian ini bertentangan dengan penelitian yang dilakukan oleh Setyaningsih (2016) dan Mahadwija (2017) yang menyatakan bahwa biaya pendidikan berpengaruh positif terhadap minat mahasiswa akuntansi mengikuti PPAk. Hasil penelitian mendukung penelitian yang dilakukan oleh Hadiprasetyo dan Sagoro (2014) dan Salindri (2014) yang menyatakan bahwa persepsi biaya pendidikan tidak berpengaruh secara signifikan terhadap minat mahasiswa akuntansi FE UNY mengikuti PPAk. Hal ini memiliki arti bahwa semakin besar biaya yang dikeluarkan, maka akan berpengaruh terhadap rendahnya minat mahasiswa akuntansi untuk mengikuti PPAk dan begitupula sebaliknya. 


\section{SIMPULAN}

Simpulan penelitian ini yaitu semakin tinggi motivasi karir, motivasi kualitas, motivasi sosial yang dimiliki oleh mahasiswa akuntansi reguler dan non reguler Universitas Udayana maka minat mahasiswa akuntansi reguler dan non reguler Universitas Udayana mengikuti PPAk akan semakin besar. Semakin besar keinginan mahasiswa akuntansi untuk mencapai karir, meningkatkan kualitas diri agar bisa menjadi profesional terutama dalam bidang akuntansi dan semakin besar keinginan mahasiswa akuntansi untuk mendapatkan pengakuan dari lingkungan sekitar akan prestasi yang telah diraihnya dan keinginan untuk menjalin hubungan dengan orang lain, maka akan semakin berminat mahasiswa tersebut untuk mengikuti PPAk. Sementara pada penelitian ini variabel biaya Pendidikan tidak mampu membuktikan pengaruh terhadap minat mahasiswa akuntansi reguler dan non reguler Universitas Udayana mengikuti PPAk. Hal ini memiliki arti bahwa tidak adanya pengaruh persepsi biaya pendidikan terhadap minat mengikuti PPAk yang disebabkan oleh besarnya biaya pendidikan yang perlu dikeluarkan untuk mengikuti PPAk. Semakin besar biaya yang dikeluarkan, maka minat mahasiswa untuk mengikuti PPAk akan cenderung menurun begitu pula sebaliknya.

Bagi peneliti selanjutnya disarankan agar dapat memperluas ruang lingkup sampel penelitian, tidak hanya pada mahasiswa akuntansi di Universitas Udayana, tetapi dapat menambahkan responden dari mahasiswa non akuntansi, para sarjana akuntansi, serta memperluas objek penelitian di luar Universitas Udayana. Selain itu, disarankan agar menambah variabel lainnya yang dapat memengaruhi minat mahasiswa untuk mengikuti Pendidikan Profesi Akuntansi, seperti variabel 
Ida Ayu Riana Puspita Dewi dan Maria Madiatrix Ratna Sari. Persepsi...

motivasi ekonomi, motivasi mencari ilmu, persepsi lama pendidikan, serta menggunakan peraturan baru mengenai Akuntan beregister Negara sebagai acuan penelitian yang diatur dalam Peraturan Menteri Keuangan Nomor 216/PMK.01/2017.

\section{REFERENSI}

Akerlof, R. J. 2006. A Theory of Social Motivation. Unpublished Manuscript: Cambridge, MA.

Alniacik, Umit., Alniacik, Esra., Akcin, Kultigin., dan Erat, Serhat. 2012. Relationships Between Career Motivation, Affective Commitment and Job Satisfaction. Procedia Social and Behavioral Sciences, 5(8): 355-362.

Aryani, Ni Putu Devi. 2015. Pengaruh Motivasi Kualitas, Motivasi Karir, Motivasi Ekonomi, dan Biaya Pendidikan pada Minat Mengikuti PPAk. Skripsi Sarjana Akuntansi Fakultas Ekonomi dan Bisnis Universitas Udayana, Bali.

Besterfield, Dale. 2003. Total Quality Manajemen. Third Edition.Pearson. New Jersey.

Buss, David. M. 1997. Human Social Motivation in Evolutionary Perspective: Grounding Terror Management Theory. Psychological Inquiry, 8(1): 22-26.

Cheng, Eddie L dan Danny C. K Ho. 2001. The Influence of Job and Career Attitudes on Learning Motivation and Transfer. Career Development International, 6(1): 20-28.

Chua, M, Rahman, M, Wong, Y, dan Loh, H. 1991. Determination of Optimal Cutting Conditions Using Design of Experiments and Optimization Techniques. International Journal of Engineering Research and Technology. J. Mach. Tools Manufact, 33(2): 297-305.

Condrorini, Galuh. 2015. Pengaruh Motivasi Terhadap Minat Mahasiswa Akuntansi Untuk Mengikuti Pendidikan Profesi Akuntansi (PPAk) (Studi Kasus di Universitas Dian Nuswantoro Semarang dan Universitas STIKUBANK Semarang). Skripsi Sarjana Akuntansi Fakultas Ekonomi dan Bisnis Universitas Dian Nuswantoro, Semarang. 
Fikri, Azharul. 2010. Persepsi Mahasiswa Akuntansi Tentang Pendidikan Profesi Akuntansi. Skripsi Sarjana Jurusan Akuntansi pada Universitas Islam Negeri Syarif Hidayatullah, Jakarta.

Goetsch, David L dan Davis, Stanley B. 2002. Quality Management, Introduction to Total Quality Management for Production, Processing, and Services. New Jersey: Prentice Hall.

Hadiprasetyo, Teguh dan Sagoro, Endra Murti. 2014. Pengaruh Motivasi, Persepsi Biaya Pendidikan dan Persepsi Masa Studi pada Minat Mengikuti PPAk. Jurnal PROFITA Universitas Negeri Yogyakarta, 2(7): 1-14.

Indrawati, Novita. 2009. Motivasi dan Minat Mahasiswa Untuk Mengikuti Pendidikan Profesi Akuntansi (PPAk). Pekbis Jurnal, 1(2): 124-130.

Kermis, George. 2011. Professional Presence and Soft Skills: A Role For Accounting Education. Journal of Instructional Pedagogies, 2(1): 1-10.

Kusumastuti, Rita dan Waluyo, Indra. 2013. Pengaruh Motivasi dan Pengetahuan UU No.5 Tahun 2011 tentang Akuntan Publik Terhadap Minat Mahasiswa Akuntansi Mengikuti Pendidikan Profesi Akuntansi (PPAk). Jurnal Nominal, II(2): $1-30$.

Lubis, Arfan Ikhsan. 2014. Akuntansi Keprilakuan. Jakarta: Salemba Empat.

Mahadwija, Hardipa Iqbal Boma. 2017. Pengaruh Pengetahuan Akuntansi, Motivasi Karir, dan Persepsi Biaya Pendidikan Terhadap Minat Mengikuti Pendidikan Profesi Akuntansi (PPAk). Skripsi Sarjana Jurusan Akuntansi pada Fakultas Ekonomi dan Bisnis Universitas Pembangunan Nasional "Veteran.", Yogyakarta.

Nurhayani, Ulfa. 2012. Pengaruh Motivasi Terhadap Minat Mahasiswa Akuntansi untuk Mengikuti Pendidikan Profesi Akuntansi (PPAk) (Studi Empiris Pada Perguruan Tinggi Swasta Medan). Jurnal Mediasi, 4(1): 59-67.

Paisey, Catriona dan Nicholas J Paisey. 2006. Cutting To The Core? A Reflection Upon Recent Education Policy Debates Within the Institute of Chartered Accountants in England and Wales. The British Accounting Review: 31-61.

Rahardian, Indra. 2008. Pengaruh Motivasi Terhadap Minat Mahasiswa Untuk Mengikuti PPAk. Skripsi Sarjana Akuntansi Fakultas Ekonomi Akuntansi Universitas Katolik Soegijapranata, Semarang.

Rahayu, Sri dan Rusmawan, R. Wedi. 2010. Analisis Faktor-Faktor Yang Mempengaruhi Minat Untuk Mengikuti Program Pendidikan Profesi 
Ida Ayu Riana Puspita Dewi dan Maria Madiatrix Ratna Sari. Persepsi...

Akuntansi (PPAk) (Survey pada Mahasiswa Dan Alumni Program Studi Akuntansi S1 Universitas X Bandung). Simposium National Akuntansi XIII : Purwokerto.

Raminten. 2012. Pengaruh Motivasi Terhadap Minat Mahasiswa Akuntansi Untuk Mengikuti Pendidikan Akuntansi (PPAk) Studi Empiris pada Mahasiswa Program Studi S1 Akuntansi Universitas Semarang. Juraksi, 1(2).

Render, Barry dan Herizer, Jay. 2004. Operations Management, International Edition, Pearson Education Inc. New Jersey: Upper Saddle River.

Robbins, Stephen P. dan Judge, Timothy. 2015. Perilaku Organisasi. Jakarta: Salemba.

Salindri, Woro. 2014. Pengaruh Motivasi, Biaya Pendidikan, Dan Lama Pendidikan Terhadap Minat Mahasiswa Untuk Mengikuti Pendidikan Profesi Akuntansi (PPAk) (Studi Kasus Pada Mahasiswa Akuntansi di Universitas Sebelas Maret Surakarta Tahun 2013). Naskah Publikasi. Universitas Muhammadiyah, Surakarta.

Schindler, Laura, Puls-Elvidge, Sarah, Welzant, Heather dan Crawford, Linda. 2015. Definitions of Quality in Higher Education: A Synthesis of the Literature. Higher Learning Research Communications, 5(3): 3-13.

Setyaningsih, Pita. 2016. Pengaruh Motivasi, Biaya Pendidikan, Dan Lama Pendidikan Terhadap Minat Mahasiswa Akuntansi Untuk Mengikuti Pendidikan Profesi Akuntansi (PPAk) (Studi Kasus Pada Mahasiswa Akuntansi di Universitas Muhammadiyah Surakarta). Naskah Publikasi. Universitas Muhammadiyah Surakarta.

Walker, J. 1998. Managing Human Resources in a Flat, Lean, and Flexible Organization: Trends for The 1990. Human Resource Planning, 11: 125132.

Weygant, Keiso, Donald E. dan Kimmel, Paul D. 1996. Auditor Liability in The UK: The Case for Reform. Critical Perspectives on Accounting And Auditing. Critical Perspectives on Accounting And Auditing, 10(3).

Wheeler, Kenneth G. 1983. Perceptions of Labor Market Variables by College Students in Business, Education, and Psychology. Journal of Vocational Behavior, 22(2): 1-11.

Widyastuti, Suryaningsum dan Juliana. 2004. Pengaruh Motivasi terhadap Minat Mahasiswa Akuntansi untuk Mengikuti Pendidikan Profesi Akuntansi (PPAk). Simposium Nasional Akuntansi VII. Denpasar-Bali. 
ISSN: 2302-8556

E-Jurnal Akuntansi Universitas Udayana Vol.25.3.Desember (2018): 2242- 2268

Zyl, Cilliers van dan Villiers, Charl de. 2011. Why Some Students Choose To Become Chartered Accountants (And Others Do Not). Meditari Accountancy Research, 19(1/2): 56-74. 